\title{
APPROXIMATELY $p$-WRIGHT AFFINE FUNCTIONS, INNER PRODUCT SPACES AND DERIVATIONS
}

\author{
ANNA BAHYRYCZ**, JANUSZ BRZDĘK* AND MAGDALENA PISZCZEK* \\ * Department of Mathematics, Pedagogical University \\ Podchorążych 2, 30-084 Kraków, Poland \\ E-mail: bahyrycz@agh.edu.pl, jbrzdek@up.krakow.pl, magdap@up.krakow.pl \\ **AGH University of Science and Technology, Faculty of Applied Mathematics \\ Mickiewicza 30, 30-059 Krakow, Poland
}

\begin{abstract}
We prove a result on hyperstability (in normed spaces) of the equation that defines the $p$-Wright affine functions and show that it yields a simple characterization of complex inner product spaces. We also obtain in this way some inequalities describing derivations, Lie derivations and Lie homomorphisms.

Key Words and Phrases: Hyperstability, $p$-Wright affine function, inner product space, derivation, Lie derivation, Lie homomorphism, fixed point theorem.

2010 Mathematics Subject Classification: 16W25, 39B52, 39B62, 39B82, 46C99, 47J99.
\end{abstract}

\section{REFERENCES}

[1] J. Aczél, J. Dhombres, Functional Equations in Several Variables, Cambridge University Press, 1989.

[2] M. Albert, J.A. Baker, Functions with bounded m-th differences, Ann. Polon. Math., 43(1983), 93-103.

[3] T. Aoki, On the stability of the linear transformation in Banach spaces, J. Math. Soc. Japan, 2(1950), 64-66.

[4] A. Bahyrycz, J. Brzdęk, M. Piszczek, J. Sikorska, Hyperstability of the Frechet equation and a characterization of inner product spaces, J. Funct. Spaces Appl., 2013(2013), Article ID 496361, 6 pages.

[5] A. Bahyrycz, M. Piszczek, Hyperstability of the Jensen functional equation, Acta Math. Hungar., 142(2014), no. 2, 353-365.

[6] D.G. Bourgin, Approximately isometric and multiplicative transformations on continuous function rings, Duke Math. J., 16(1949), 385-397.

[7] D.G. Bourgin, Classes of transformations and bordering transformations, Bull. Amer. Math. Soc., 57(1951), 223-237.

[8] N. Brillouët-Belluot, J. Brzdęk, K. Ciepliński, On some recent developments in Ulam's type stability, Abstr. Appl. Anal., 2012(2012), Article ID 716936, 41 pages.

[9] J. Brzdęk, Stability of the equation of the p-Wright affine functions, Aequationes Math., 85(2013), no. 3, 497-503.

[10] J. Brzdęk, Remarks on hyperstability of the Cauchy functional equation, Aequationes Math., 86(2013), no. 3, 255-267.

[11] J. Brzdęk, Hyperstability of the Cauchy equation on restricted domains, Acta Math. Hungar., 141(2013), no. 1-2, 58-67. 
[12] J. Brzdęk, J. Chudziak, Z. Páles, A fixed point approach to stability of functional equations, Nonlinear Anal., 74(2011), 6728-6732.

[13] J. Brzdęk, K. Ciepliński, A fixed point approach to the stability of functional equations in nonArchimedean metric spaces, Nonlinear Anal., 74(2011), 6861-6867.

[14] J. Brzdęk, L. Cădariu, K. Ciepliński, Hyperstability and superstability, Abst. Appl. Anal., 2013(2013), Article ID 401756, 13 pages.

[15] J. Brzdęk, K. Ciepliński, Fixed point Ttheory and the Ulam stability, J. Funct. Spaces, 2014(2014), Article ID 829419, 16 pages.

[16] J. Brzdęk, A. Fošner, Remarks on the stability of Lie homomorphisms, J. Math. Anal. Appl., 400(2013), 585-596.

[17] L. Cădariu, L. Găvruţa, P. Găvruța, Fixed points and generalized Hyers-Ulam stability, Abstr. Appl. Anal., 2012(2012), Article ID 712743, 10 pages.

[18] J. Chudziak, Stability of the homogeneous equation, Demonstratio Math., 31(1998), 765-772.

[19] K. Ciepliński, Applications of fixed point theorems to the Hyers-Ulam stability of functional equations - a survey, Ann. Funct. Anal., 3(2012), 151-164.

[20] Z. Daróczy, K. Lajkó, R. L. Lovas, G. Maksa, Z. Páles, Functional equations involving means, Acta Math. Hungar., 116(2007), 79-87.

[21] Z. Gajda, On stability of additive mappings, Int. J. Math. Math. Sci., 14(1991), 431-434.

[22] A. Gilányi, Z. Páles, On Dinghas-type derivatives and convex functions of higher order, Real Anal. Exchange, 27(2001/2002), 485-493.

[23] E. Gselmann, Hyperstability of a functional equation, Acta Math. Hungar., 124(2009), 179-188.

[24] D.H. Hyers, On the stability of the linear functional equation, Proc. Natl. Acad. Sci. U.S.A. 27(1941), 222-224

[25] D.H. Hyers, Transformations with bounded mth differences, Pacific J. Math., 11(1961), 591-602.

[26] D.H. Hyers, G. Isac, Th.M. Rassias, Stability of Functional Equations in Several Variables, Birkhäuser, Boston, 1998.

[27] D.H. Hyers, S.M. Ulam, On approximate isometries, Bull. Amer. Math. Soc., 51(1945), $288-292$.

[28] D.H. Hyers, S.M. Ulam, Approximate isometries of the space of continuous functions, Ann. Math., 48(1947), 285-289.

[29] D. H. Hyers, S. M. Ulam, Approximately convex functions, Proc. Amer. Math. Soc., 3(1952), $821-828$.

[30] W. Jabłoński, On a class of sets connected with a convex function, Abh. Math. Sem. Univ. Hamburg, 69(1999), 205-210.

[31] W. Jabłoński, Sum of graphs of continuous functions and boundedness of additive operators, J. Math. Anal. Appl., 312(2005), 527-534.

[32] W. Jabłoński, Stability of homogeneity almost everywhere, Acta Math. Hungar., 117(2007), 219-229.

[33] K.W. Jun, D.W. Park, Almost derivations on the Banach algebra $C^{n}[0,1]$, Bull. Korean Math. Soc., 33(1996), 359-366.

[34] S.M. Jung, Hyers-Ulam Stability of Functional Equations in Mathematical Analysis, Hadronic Press, Inc., Palm Harbor, FL, 2001.

[35] S.M. Jung, Hyers-Ulam-Rassias Stability of Functional Equations in Nonlinear Analysis, Springer Optimization and Its Applications, vol. 48, Springer, New York-Dordrecht-HeidelbergLondon, 2011

[36] M. Kuczma, An Introduction to the Theory of Functional Equations and Inequalities, Cauchy's Equation and Jensen's Inequality, Birkhäuser, 2nd edition, 2009.

[37] G. Maksa, The stability of the entropy of degree alpha, J. Math. Anal. Appl., 346(2008), 17-21.

[38] G. Maksa, K. Nikodem, Z. Páles, Results on t-Wright convexity, C.R. Math. Rep. Acad. Sci. Canada, 13(1991), 274-278.

[39] G. Maksa, Z. Páles, Hyperstability of a class of linear functional equations, Acta Math. Acad. Pedag. Nyìregyháziensis, 17(2001), 107-112.

[40] T. Miura, H. Oka, G. Hirasawa, S.E. Takahasi, Superstability of multipliers and ring derivations on Banach algebras, Banach J. Math. Anal., 1(2007), 125-130. 
[41] M.S. Moslehian, Ternary derivations, stability and physical aspects, Acta Appl. Math., $\mathbf{1 0 0}(2008)$, 187-199.

[42] Z. Moszner, On the stability of functional equations, Aequationes Math., 77(2009), 33-88.

[43] A. Najati, C. Park, Stability of homomorphisms and generalized derivations on Banach algebras, J. Inequal. Appl., 2009(2009), 1-12.

[44] K. Nikodem, Z. Páles, On approximately Jensen-convex and Wright-convex functions, C.R. Math. Rep. Acad. Sci. Canada, 23(2001), 141-147.

[45] M. Piszczek, Remark on hyperstability of the general linear equation, Aequationes Math., 88(2014), 163-168.

[46] Th.M. Rassias, On the stability of the linear mapping in Banach spaces, Proc. Amer. Math. Soc., 72(1978), 297-300.

[47] Th.M. Rassias, On a modified Hyers-Ulam sequence, J. Math. Anal. Appl., 158(1991), $106-113$.

[48] J. Tabor, Tabor, Homogeneity is superstable, Publ. Math. Debrecen, 45(1994), 123-130.

[49] E.M. Wright, An inequality for convex functions, Amer. Math. Monthly, 61(1954), 620-622.

Received: May 29, 2014; Accepted: March 26, 2015. 